\title{
Hemocyanins in the Immunotherapy of Superficial Bladder Cancer
}

\author{
Sergio Arancibia ${ }^{1}$, Fabián Salazar ${ }^{1}$ and María Inés Becker ${ }^{1,2}$ \\ ${ }^{1}$ Fundación Ciencia y Tecnología para el Desarrollo (FUCITED) \\ 2Biosonda Corporation \\ 1,2Chile
}

\section{Introduction}

Chemo- and immunotherapeutic approaches have been used to prevent recurrence of transitional cell carcinoma (TCC), the most common type of superficial bladder cancer (SBC). The bacillus Calmette-Guérin (BCG) vaccine for tuberculosis, which consists of an attenuated form of Mycobacterium bovis, is the most commonly used immunotherapeutic agent (Morales et al., 1976). Despite the successful results achieved with BCG, its serious side effects have led researchers to investigate other immunostimulatory substances. In the early 1970s, Olsson and collaborators reported that subcutaneous stimulation with keyhole limpet hemocyanin (KLH) from the Californian marine gastropod Megathura crenulata significantly reduced SBC recurrence frequency in TCC patients without any toxic side effects, making it ideal for long-term repetitive treatments (Olsson et al., 1974). These results provided promising support for the use of mollusk hemocyanins as alternative agents in SBC immunotherapy.

Hemocyanins, blue respiratory glycoproteins that were discovered in 1878 by Léon Fredericq (Ghiretti-Magaldi \& Ghiretti, 1992), are found freely dissolved in the blood of some mollusks and arthropods. These proteins are giant structures with molecular weights between 4 and $8 \mathrm{MDa}$, and they exhibit some of the most complex and sophisticated quaternary structures known. Hemocyanins are part of the type-3 group of copper proteins that includes phenoloxidases and tyrosinases (Decker \& Tuczek, 2000). These proteins contain active copper-containing sites in which the $\mathrm{Cu}(\mathrm{I}, \mathrm{I})$ state is oxidized to the $\mathrm{Cu}(\mathrm{II}, \mathrm{II})$ state, thus accounting for their distinctive deep blue color. Because of these properties, the biochemistry of hemocyanins has been intensively studied (van Holde \& Miller, 1995). The pioneering work of Weigle in the 1960s on the immunochemical properties of KLH demonstrated its remarkable immunostimulatory properties in an experimental animal model (Weigle, 1964). These results were quickly incorporated into clinical studies to evaluate its immunological effects.

Because the primary amino acid sequences of mollusk hemocyanins are highly divergent from mammalian sequences, they are strongly recognized by the immune system, resulting in potent immunogenicity; these proteins can be used therapeutically as non-specific immunostimulants with beneficial clinical outcomes. Moreover, hemocyanins have been extensively used as carriers to generate antibodies against diverse hapten molecules and 
peptides and to induce antigen-specific CD8+ and CD4+ T cell responses (Harris \& Markl, 1999). Currently, hemocyanins are used as carrier-adjuvants for several tumor-associated antigens (TAAs), such as glycolipid and glycoprotein (mucin-like) antigens, in experimental therapeutic vaccines against certain cancers, including melanomas, sarcomas, breast, prostate, ovary and lung (Musselli et al., 2001; Schumacher, 2001; Zhu et al., 2009; Del Campo et al., 2011). Other therapeutic strategies that use hemocyanins include dendritic cell (DC) vaccines pulsed with tumor lysates to enhance interferon gamma (IFN- $\gamma$ ) production by tumor-reactive T cells (Timmerman \& Levy, 2000; Shimizu et al., 2001; Millard et al., 2003; Lopez et al., 2009; Jacobs et al., 2010; Lesterhuis et al., 2011) and anti-idiotype vaccines for some types of B cell malignancies (Leitch \& Connors, 2005; Kafi et al., 2009). KLH has been the gold standard for these applications for over 40 years simply because it was used in earlier studies instead of other hemocyanins (Harris \& Markl, 1999). The first studies used a research-grade KLH (non-GMP) containing different levels of endotoxin (Vandenbark et al., 1981); since then, several companies have produced clinical-grade KLH.

The versatile properties of KLH in biomedical and biotechnological applications have led to increasing commercial demand and growing interest in finding new, alternative hemocyanins with similar or more potent immunomodulatory properties. Although the KLH gene has been cloned, and its amino acid sequence is known, it has not been possible to express a heterologous protein, mainly because of its complex structure (Lieb et al., 2001; Markl et al., 2001; Altenhein et al., 2002). Therefore, this protein can be obtained only from its natural source. Several hemocyanins from other species of mollusks have been studied biochemically and immunologically, including Haliotis tuberculata ( $\mathrm{HtH}$, Abalon) (Markl et al., 2001); Helix vulgarix ( $\mathrm{HpH}$, Vineyard snail), Rapana venosa ( $\mathrm{RvH}$, Asian rapa whelk), and Rapana thomasiana (RtH, Black sea murex) (Dolashka-Angelova et al., 2003; 2008; 2010); and Concholepas concholepas (CCH, Loco), which is found on the pacific Chilean coast (De Ioannes et al., 2004). Only CCH has been pre-clinically evaluated in a murine experimental model of SBC and may be considered a safe alternative therapy (Moltedo et al., 2006; Atala, 2006). Although $\mathrm{KLH}$ and $\mathrm{CCH}$ have different origins and structure they have similar immunostimulatory capacities, suggesting that a conserved pattern common to both hemocyanins induces an ancient immunological mechanism (Moltedo et al., 2006). Interestingly, we have described a new hemocyanin from Fissuerella latimarginata (FLH) that exhibits higher immunogenicity than either $\mathrm{CCH}$ or $\mathrm{KLH}$, opening a new avenue for research on the use of hemocyanins (Espinoza et al., 2006; Arancibia et al., 2010).

Notwithstanding the biomedical interest in mollusk hemocyanins, the molecular and cellular bases of their adjuvant/immunostimulatory capacity in SBC remain poorly understood. Currently, we know that hemocyanins are able to drive the differentiation of $\mathrm{T}$ helper (Th) cells toward a Th1 phenotype, characterized by increased secretion of IFN- $\gamma$ and the production of IgG2a isotype antibodies (Moltedo et al., 2006).

In this chapter, we will review what is currently known about the experimental and clinical uses of mollusk hemocyanins as non-specific immunostimulants to prevent SBC recurrence, including the details of their intricate structure and the immunologic mechanisms that have been proposed to explain their antitumor activity.

\section{Structure of the mollusk hemocyanins}

Because of their enormous size, mollusk hemocyanins are easily observed by transmission electron microscopy (TEM) using negative staining. These molecules have a cylindrical form 
with an external diameter of approximately $350 \mathrm{~nm}$ and length of approximately $400 \mathrm{~nm}$. Fig. 1 shows the characteristic appearance of gastropod hemocyanins under TEM.
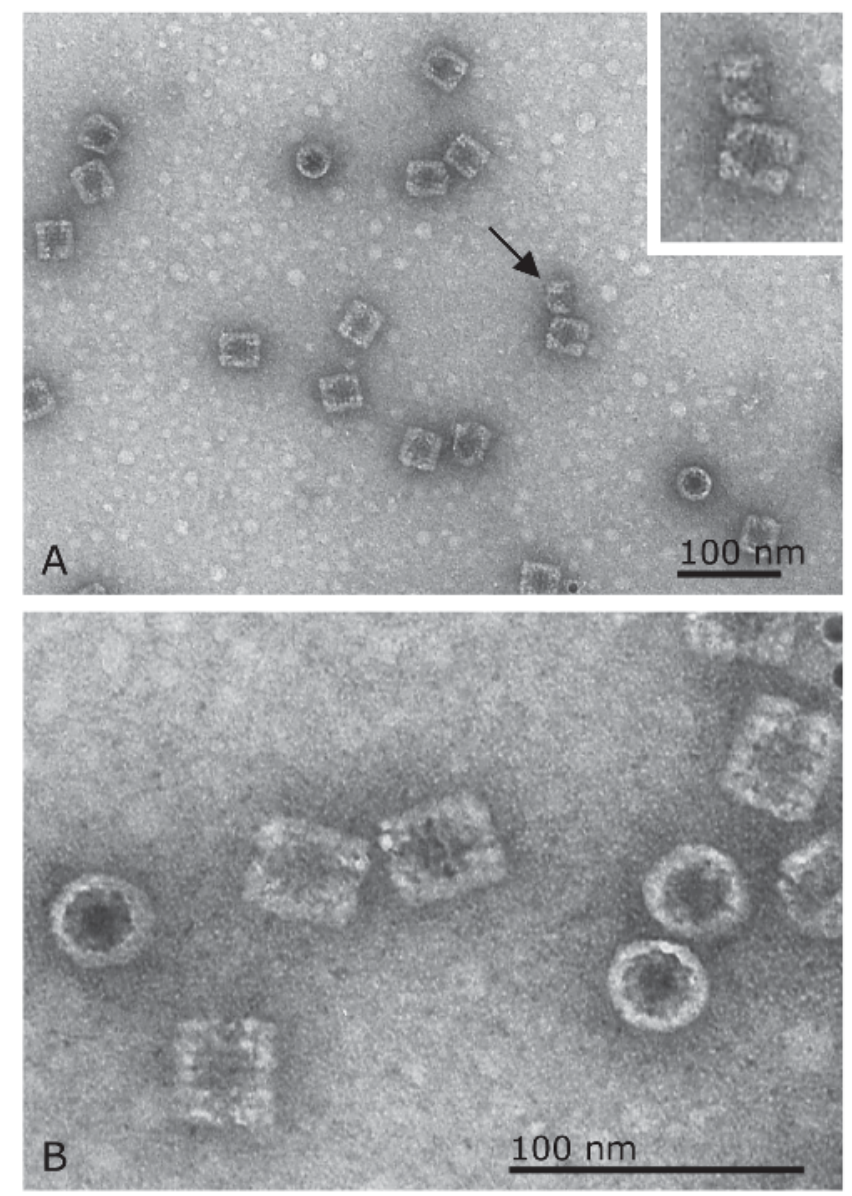

Fig. 1. Electron microscopy of negatively stained C. concholepas hemocyanin molecules. A. Low magnification micrographs of a preparation of the protein showing their characteristic hollow cylinder form. The images show the top (circles) and lateral (rectangles) views of the molecule. The arrow shows a decamer. B. High magnification images of hemocyanin molecules showing their intricate structure. The side views show the proteins' characteristic didecameric form with subunits arranged in layers.

Many experimental studies on hemocyanins, using different dissociation and association conditions and physicochemical and biochemical methods, have helped to elucidate their hierarchically organized structure (van Holde \& Miller, 1995; Harris \& Markl, 1999). As shown in Fig. 2, the basic structure of hemocyanins is composed of ten subunits that are selfassembled into a hollow cylinder, a structure known as a decamer, with a lumen that is narrowed by a complex collar (Harris et al., 1993; Cuff et al., 1998; Decker et al., 2007). In 
gastropods, the decamers can self-associate face-to-face to form stable dimers or didecamers, which display an intricate internal arrangement and result in the formation of extremely large structures with approximate D5 symmetry (Orlova et al., 1997). Hemocyanin subunits have a molecular weight ranging from 350 to $450 \mathrm{kDa}$ and are composed of a string of seven or eight globular domains called functional units (FUs), each with a molecular weight between 35 and $50 \mathrm{kDa}$. These FUs are connected by a short flexible linker peptide strand of 10 to 15 amino acid residues. Each FU has two well-separated copper atoms that reversibly capture $\mathrm{O}_{2}$ molecules; one is called the A site, which is located towards the N-terminus, and the other is called the B site and is located downstream of the polypeptide (van Holde et al., 2001).

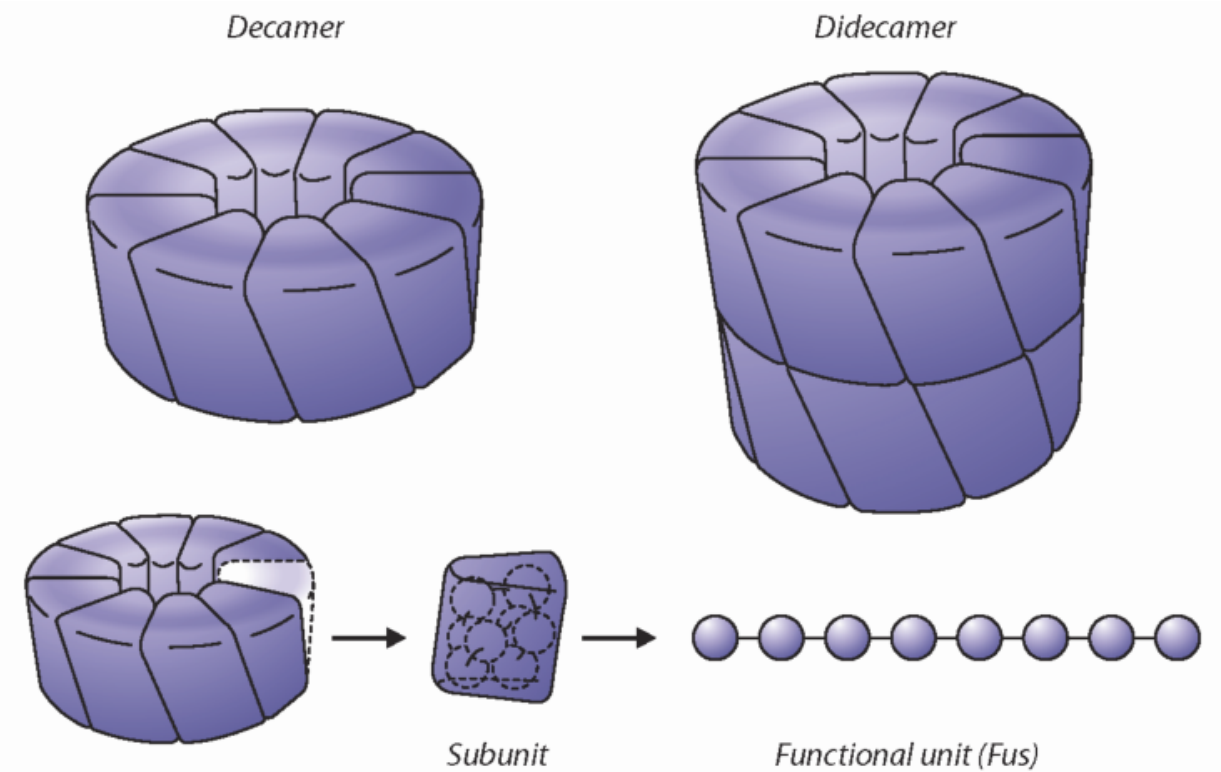

Fig. 2. Model of the structure of mollusk hemocyanin. The basic structure of a mollusk hemocyanin is a decamer, which is formed by the association of 10 polypeptides or subunits. In hemocyanins from some species of mollusk, such as gastropods, including KLH and $\mathrm{CCH}$, the decamers are associated in pairs to form very large molecules called didecamers. The subunit consists of seven or eight globular domains linked by a peptide spacer consisting of 10 to 15 amino acid residues, similar to a pearl necklace. Each of these globular domains has a pair of copper atoms that reversibly bind one oxygen molecule, which is why they are called functional units.

Knowledge of the carbohydrate moieties present in mollusk hemocyanins has been essential for understanding their organization, antigenicity and biomedical properties (Paccagnella et al., 2004; Siddiqui et al., 2007). In fact, several authors have reported that hemocyanin carbohydrates may play a role in their immunostimulatory effects. The high carbohydrate content of hemocyanins, up to $9 \%(\mathrm{w} / \mathrm{w})$, has been measured by different methods, including the use of lectins and high-pressure liquid chromatography-tandem mass spectrometry (HPLC-MS/MS). The presence of numerous N-glycosylation sites and a reduced number of O- 
glycosylation sites has been established (Dolashka-Angelova et al., 2003; Gielens et al., 2004; Idakieva et al., 2004; Gatsogiannis \& Markl, 2009; Dolashka et al., 2010). Mollusk hemocyanins contain diverse sugar moieties, including mannose, D-galactose, fucose, N-acetyl-Dgalactosamine and $\mathrm{N}$-acetyl-glucosamine residues, with mannose being the most abundant (Harris \& Markl, 1999). Hemocyanins also contain monosaccharides that are not usually found in animal proteins, such as xylose (Lommerse et al., 1997).

\subsection{KLH and $\mathrm{CCH}$}

Although $\mathrm{KLH}$ and $\mathrm{CCH}$ each have two subunits that constitute the basic structure known as a decamer, closer analysis revealed unique differences. Native gel electrophoresis has shown that KLH is made up of two different non-covalently linked subunits called KLH1 (350 KDa) and KLH2 (350 KDa) that do not display shared epitopes (Swerdlow et al., 1996). Using the same approach, it was demonstrated that $\mathrm{CCH}$ is also made up of two different subunits, CCHA (405 kDa) and CCHB $(350 \mathrm{kDa})$, that contain common and specific epitopes (Oliva et al., 2002; De Ioannes et al., 2004). In KLH, the subunits form homodidecamers (i.e., the molecules are formed from either KLH1 or KLH2 subunits). However, in $\mathrm{CCH}$ the subunits form heterodidecamers (i.e., the molecules are formed by pairing the two different subunits). In addition, purified KLH requires divalent cations in storage buffers to maintain the stability of its quaternary structure, whereas CCH does not (De Ioannes et al., 2004); this is probably a consequence of the higher hydrophobicity of $\mathrm{CCH}$ (Leyton et al., 2005). Despite these differences, the immunogenic properties of $\mathrm{CCH}$ and $\mathrm{KLH}$ are similar. $\mathrm{CCH}$ has been successfully used as a carrier protein to generate antibodies against hapten molecules and peptides (Becker et al., 1998; Torres et al., 1999; Mura et al., 2002; Duvillie et al., 2003; Manosalva et al., 2004; Cancino et al., 2007; Gravotta et al., 2007; Matus et al., 2007; Grenegard et al., 2008); as a carrier in vaccines (Miller et al., 2006; Mauldin \& Miller, 2007; Pilon et al., 2007) and as an experimental antigen (Becker et al., 2007; Moltedo et al., 2009).

Several studies have demonstrated that KLH contains approximately $3.2 \%(\mathrm{w} / \mathrm{w})$ carbohydrate residues, displaying specific structural motifs on N-glycans, such as Fuc(alpha1-3)GalNAc, Gal-(beta1-6)Man-, Gal(beta1-4)Fuc-, and Gal(beta1-4)Gal(beta(14)Fuc-, which are thought to contribute to its non-specific immunostimulatory capacities in SBC (Wuhrer et al., 2004). Our knowledge of the corresponding oligosaccharide composition of $\mathrm{CCH}$ is very limited. However, we have demonstrated using selective glycosidase treatments and electrophoretic analysis that sugar moieties account for $3.1 \%(\mathrm{w} / \mathrm{w})$ of the mass of $\mathrm{CCH}$. A comparative analysis using lectin staining indicated that mannose is the only exposed carbohydrate common to CCH and KLH (Becker et al., 2009). It is important to note that, despite the differences in carbohydrate composition between $\mathrm{KLH}$ and $\mathrm{CCH}$, both proteins have similar immunogenicity and immunotherapeutic capacity in SBC, suggesting that other factors are responsible for this effect. We assume that the primary structure of these proteins contains the determining factor because they share regions of high sequence homology (van Holde et al., 2001; Manubens et al., 2010). These regions were confirmed in antibody cross-reactivity experiments that revealed the presence of common or mimetic epitopes in $\mathrm{CCH}$ and KLH (Oliva et al., 2002).

\section{Use of hemocyanins in experimental SBC}

Rats and various strains of mice have been used as in vivo SBC models to evaluate therapeutic agents because bladder tumors in these rodents have similarities with human 
tumors. In addition, tumor cells can be established subcutaneously (heterotopically) or in the bladder (orthotopically) by either transplantation or chemical induction, allowing the investigation of clinical aspects such as pharmacokinetics and toxicity (Gunther et al., 1999; Linn et al., 2000; Arentsen et al., 2009).

The first controlled study of a hemocyanin as immunotherapy in the treatment of superficial bladder cancer was published in the 1980s by the Lamm group (Lamm et al., 1981). They developed the mouse bladder tumor-2 cell (MBT-2) transplantable murine model of SBC and demonstrated that pre-immunization with $200 \mu \mathrm{g}$ of KLH three weeks prior to subcutaneous injection with MBT-2, followed by intralesional immunotherapy with $50 \mu \mathrm{g}$ one and seven days after inoculation, resulted in a significant reduction in tumor growth and a prolongation of animal survival. Later, other studies by the same researchers evaluated non-specific immunotherapeutic regimens (Lamm et al., 1982). Animals received an intradermal MBT-2 inoculation, and the immunotherapy was administered intralesionally one day after tumor transplantation. Tumors were excised at a volume of 400 $\mathrm{mm}^{3}$, and the animals were re-challenged with tumor cells, treated again, and followed for tumor incidence, growth rate and survival. This study demonstrated that KLH had a weak antitumor effect compared with the response to BCG. In 1986, Lau and collaborators studied the same response, this time comparing intraperitoneal and intralesional administration of the agents. $\mathrm{C} 3 \mathrm{H} / \mathrm{He}$ mice were injected subcutaneously with $5 \times 10^{4}$ tumor cells. After that, the mice received either intraperitoneal or intralesional treatments (50 $\mu \mathrm{g} \mathrm{KLH})$; these experiments demonstrated that the intralesional route was more effective than intraperitoneal administration for tumor growth inhibition (Lau et al., 1986).

Lamm's group also evaluated the possible additive and/or synergistic effects of KLH immunotherapy in the MBT-2 model in conjunction with other treatments, such as IFN-a. Tumor cells were transplanted subcutaneously without prior immunization. Treatment was given intraperitoneally twice weekly for three weeks, except for BCG, which was administered once a week. Significant reductions in tumor incidence relative to the controls were observed in groups receiving KLH (42\%), IFN-a (42\%) and KLH + IFN-a (17\%) (Riggs et al., 1992). The following year, the same group compared two alternative immunotherapies in the MBT-2 model: crude KLH and Immucothel, a clinical-grade KLH from Biosyn Arzneimittel $\mathrm{GmbH}$. Mice were sensitized with 50 or $100 \mu \mathrm{g} \mathrm{KLH}$, and 21 days later, $10^{3}$ tumor cells were injected. Intralesional treatment with 50 or $100 \mu \mathrm{g} \mathrm{KLH}$ was performed on days 1, 7 and 13 or 14 . Crude KLH required either immunization before tumor transplant or frequent therapy after transplantation to be effective. In addition, Immucothel required preimmunization to be effective, even with an increased frequency and dosage of the posttransplant immunizations. In a subsequent study, the endotoxin contamination of KLH was demonstrated to be partly responsible for the antitumor activity because treatment with endotoxin alone resulted in a significant reduction of tumor growth and mortality $(50 \%$ survival) (Lamm et al., 1993). Moreover, KLH +100 Endotoxin Units (EU) resulted in complete inhibition of tumor growth and $100 \%$ survival. KLH + 1000 EU appeared to reduce the antitumor response (50\% survival), suggesting that endotoxin may interfere with the response to purified KLH. Finally, endotoxin-free KLH induced antitumor responses $(50 \%$ survival). However, pre-immunization was required for KLH to exert a significant (75\% survival) antitumor effect (Lamm et al., 1993).

Walsh and collaborators studied KLH immunotherapy in two different models with no promising results. First, they transplanted $2.5 \times 10^{6}$ MBT-2 tumor cells subcutaneously after pre-immunization 20 days prior. Treatment was given on days 1, 8 and 18 in the form of 
subcutaneous or intralesional injection of $50 \mu \mathrm{g} \mathrm{KLH}$. The results showed no difference between the control and treated groups in terms of either tumor growth or animal survival. Alternatively, they transplanted $2.1 \times 10^{6} \mathrm{MBT}-2$ tumor cells into the bladder of $\mathrm{C} 3 \mathrm{H} / \mathrm{He}$ mice. The bladder was irrigated with $1.5 \mathrm{mg} \mathrm{N}$-methyl-N-nitrosourea 48 hours prior. The treatment group was injected with $50 \mu \mathrm{g} \mathrm{KLH}$ on day 1 , and the bladders were instilled with $200 \mu \mathrm{g} \mathrm{KLH}$ on days 14 and 21. There was no significant difference from the control group (Walsh et al., 1983). Using a similar model, Marsh and collaborators demonstrated that intravesical immunotherapy with Corynebacterium parvum and Allium sativum was more effective than KLH and slightly more effective than BCG. MBT-2 cells were delivered into the bladder transurethrally using a small catheter, and the immunotherapy was administered directly into the bladder via this catheter on day 1 or day 6 , or both. The authors associated the lack of a significant effect with inappropriate dosage or insufficient stimulation of the immune system (Marsh et al., 1987). Later, the antitumor activity and potential toxicity of a clinical grade KLH preparation named KLH-Immune Activator (KLHIA) was examined. Mice were immunized subcutaneously with KLH-IA two weeks prior to intravesical implantation with $2 \times 10^{4} \mathrm{MB}-49$ tumor cells. Treatment consisted of intravesical KLH-IA (10 or $100 \mu \mathrm{g})$ 1, 4, 7, 14 and 21 days after implantation. By four weeks after implantation, tumor outgrowth in the treated groups was significantly decreased. Prior subcutaneous immunization was required to elicit the antitumor activity of KLH-IA. Animals treated with a dissociated form of KLH showed decreased tumor outgrowth, but this was not significant. A separate toxicity study in which KLH-IA was given subcutaneously $(4 \mathrm{mg} / \mathrm{kg})$, intraperitoneally $(40 \mathrm{mg} / \mathrm{kg})$ or intravesically $(40 \mathrm{mg} / \mathrm{kg})$ reported no significant gross or histopathological abnormalities, except for mild to moderate papillary hyperplasia in all catheterized animals (Swerdlow et al., 1994).

A third model developed by Recker and collaborators also showed the effectiveness of KLH. Bladder carcinoma was induced in Wistar rats using N-butyl-N-(4-hydroxybutyl) nitrosamine (BBN). Stimulation of the rats with $12.5 \mathrm{mg}$ of KLH administered intravesically and $0.5 \mathrm{mg}$ administered subcutaneously twice weekly after sensitization with $1 \mathrm{mg}$ subcutaneous KLH resulted in a reduction in BBN-induced bladder tumors. These results confirmed that effective induction of an immune response is important for the control of tumor development because immune-suppressed rats treated with cyclosporine A (CsA) showed enhanced bladder tumor expansion compared with rats treated with $0.05 \% \mathrm{BBN}$ alone (Recker \& Rubben, 1989). A subsequent study distinguished between intravesical and subcutaneous application to determine the most effective treatment regime. Five weeks after the completion of tumor induction with $0.05 \%$ BBN solution, exophytic bladder tumors appeared in all control animals. In group 2, which was given KLH via intravesical instillation, tumors developed in $73.5 \%$ of cases. In group 1 , with subcutaneous administration, tumors developed in only $50 \%$ of cases. The tumor growth was significantly slower in group 1 than group 2 (Linn et al., 2000).

The results described above demonstrated promising potential for the use of KLH in SBC therapy. More recently, preclinical studies have proven hemocyanin from Concholepas concholepas $(\mathrm{CCH})$ to be a reliable alternative to KLH (Moltedo et al., 2006). C3H/He mice were primed with $\mathrm{CCH}$ before subcutaneous implantation of MBT-2 cells. Treatment consisted of a subcutaneous dose of $\mathrm{CCH}(1 \mathrm{mg}$ or $100 \mu \mathrm{g})$ at different intervals after implantation. The results demonstrated a significant antitumor effect, as indicated by decreased tumor growth and incidence, prolonged survival and a lack of toxic effects. These results were similar to those achieved with KLH. 


\begin{tabular}{|c|c|c|c|c|c|}
\hline Model & Priming1 & $\begin{array}{l}\text { Via } \\
\text { Administration }\end{array}$ & $\begin{array}{l}\text { Therapeutic } \\
\text { Dosage and } \\
\text { Schedule }^{2}\end{array}$ & Results & Reference \\
\hline \multirow[t]{10}{*}{ Mouse, MBT-2 } & $\begin{array}{l}\text { Yes } \\
200 \mu \mathrm{g}\end{array}$ & Intralesional & $\begin{array}{l}50 \mu \mathrm{g} \\
\text { Days: } 1 \text { and } 7 .\end{array}$ & $\begin{array}{l}\text { Significant reduction of } \\
\text { tumor growth and } \\
\text { survival with KLH. }\end{array}$ & $\begin{array}{l}\text { Lamm } \\
\text { et al.1981 }\end{array}$ \\
\hline & No & Intralesional & Day: 1 & $\begin{array}{l}\text { KLH presented a minor } \\
\text { antitumor effect } \\
\text { compared with BCG. }\end{array}$ & $\begin{array}{l}\text { Lamm } \\
\text { et al. } 1982\end{array}$ \\
\hline & Yes & $\begin{array}{l}\text { Subcutaneous or } \\
\text { intralesional }\end{array}$ & $\begin{array}{l}50 \text { or } 200 \mu \mathrm{g} \\
\text { Days: } 1,8 \text { and } 18 \\
\text { or } 1,14 \text { and } 21 .\end{array}$ & $\begin{array}{l}\text { KLH do not show } \\
\text { difference with controls } \\
\text { in tumor growth or } \\
\text { animal survival. }\end{array}$ & $\begin{array}{l}\text { Walsh } \\
\text { et al. } 1983\end{array}$ \\
\hline & No & $\begin{array}{l}\text { Intraperitoneal v/s } \\
\text { intralesional }\end{array}$ & $50 \mu \mathrm{g}$ & $\begin{array}{l}\text { Intralesional route of } \\
\text { inoculation of KLH was } \\
\text { more effective. }\end{array}$ & $\begin{array}{l}\text { Lau } \\
\text { et al. } 1986\end{array}$ \\
\hline & No & Intravesical & $\begin{array}{l}50 \mu \mathrm{g} \\
\text { Days: } 1 \text { or } 6, \\
\text { or both. }\end{array}$ & $\begin{array}{l}\text { Immunotherapy with } C \text {. } \\
\text { parvum and } A \text {. sativum } \\
\text { was more effective than } \\
\text { KLH. }\end{array}$ & $\begin{array}{l}\text { Marsh } \\
\text { et al.1987 }\end{array}$ \\
\hline & No & Intraperitoneal & $\begin{array}{l}50 \mu \mathrm{g} \\
\text { Twice weekly for } \\
3 \text { weeks. }\end{array}$ & $\begin{array}{l}\text { Better response in the } \\
\text { animals treated with } \\
\text { KLH more INF-a. }\end{array}$ & $\begin{array}{l}\text { Riggs } \\
\text { et al. } 1992\end{array}$ \\
\hline & $\begin{array}{l}\text { Yes } \\
50 \text { or } 100 \mu \mathrm{g}\end{array}$ & Intralesional & $\begin{array}{l}50 \text { or } 100 \mu \mathrm{g} \\
\text { Days: } 1,7 \text { and } \\
13 \text { or } 14 .\end{array}$ & $\begin{array}{l}\text { Required pre- } \\
\text { immunization of KLH } \\
\text { and Immucothel to be } \\
\text { effective. }\end{array}$ & $\begin{array}{l}\text { Lamm } \\
\text { et al. 1993a }\end{array}$ \\
\hline & $\begin{array}{l}\text { Yes } \\
50 \text { or } 100 \mu \mathrm{g}\end{array}$ & Intralesional & $\begin{array}{l}50 \text { or } 100 \mu g \\
\text { Days: } 1,7 \text { and } \\
13 \text { or } 14 .\end{array}$ & $\begin{array}{l}\text { Endotoxin } \\
\text { contamination of KLH } \\
\text { was responsible in } \\
\text { part for the antitumor } \\
\text { activity. }\end{array}$ & $\begin{array}{l}\text { Lamm } \\
\text { et al. 1993b }\end{array}$ \\
\hline & $\begin{array}{l}\text { Yes } \\
200 \text { to } 400 \mu \mathrm{g}\end{array}$ & Subcutaneous & $\begin{array}{l}1 \mathrm{mg} \\
\text { Days: } 1 \text { to } 6 \text { or } \\
100 \mu \mathrm{g} \\
\text { Days: } 1,3,5, \\
7 \text { and } 9 .\end{array}$ & $\begin{array}{l}\text { Significant reduction of } \\
\text { tumor growth and } \\
\text { survival with } \mathrm{CCH} \text {. }\end{array}$ & $\begin{array}{l}\text { Moltedo } \\
\text { et al. } 2006\end{array}$ \\
\hline & $\begin{array}{l}\text { Yes } \\
200 \mu \mathrm{g}\end{array}$ & Subcutaneous & $\begin{array}{l}100 \mu \mathrm{g} \\
\text { Days: } 1,3,5, \\
7 \text { and } 9 .\end{array}$ & $\begin{array}{l}\text { Better antitumor effect } \\
\text { with } \\
\text { CCHA subunit than } \\
\text { CCHB subunit. }\end{array}$ & $\begin{array}{l}\text { Becker } \\
\text { et al. } 2009\end{array}$ \\
\hline Mouse, MB-49 & $\begin{array}{l}\text { Yes } \\
100 \mu \mathrm{g}\end{array}$ & Intravesical & $\begin{array}{l}10 \text { or } 100 \mu \mathrm{g} \\
\text { Days: } 1,4,7, \\
14 \text { and } 21 .\end{array}$ & $\begin{array}{l}\text { Prior immunization of } \\
\text { KLH-IA was required to } \\
\text { elicit antitumor } \\
\text { activity. }\end{array}$ & $\begin{array}{l}\text { Swerdlow } \\
\text { et al. } 1994\end{array}$ \\
\hline \multirow[t]{2}{*}{$\begin{array}{l}\text { Rats, tumor } \\
\text { induction with } \\
\mathrm{BBN}^{3}\end{array}$} & $\begin{array}{l}\text { Yes } \\
1 \mathrm{mg}\end{array}$ & $\begin{array}{l}\text { Intravesical and } \\
\text { subcutaneous }\end{array}$ & $\begin{array}{l}12.5 \mathrm{mg} \text { and } 500 \\
\mu \mathrm{g} \\
\text { Twice weekly. }\end{array}$ & $\begin{array}{l}\text { Reduction of bladder } \\
\text { tumors with KLH. }\end{array}$ & $\begin{array}{l}\text { Recker } \\
\text { et al. } \\
1989\end{array}$ \\
\hline & $\begin{array}{l}\text { Yes } \\
1 \mathrm{mg}\end{array}$ & $\begin{array}{l}\text { Intravesical v/s } \\
\text { subcutaneous }\end{array}$ & $\begin{array}{l}500 \mu \mathrm{g} \\
\text { Twice weekly for } \\
8 \text { weeks. }\end{array}$ & $\begin{array}{l}\text { Subcutaneous route of } \\
\text { KLH was more effective } \\
\text { than intravesical route. }\end{array}$ & $\begin{array}{l}\text { Linn } \\
\text { et al. } 2000\end{array}$ \\
\hline
\end{tabular}

${ }^{1}$ Priming: Usually, around two weeks prior to tumor challenge. ${ }^{2}$ Immunotherapy after tumor transplantation. ${ }^{3}$ BNN: N-butyl-N-(4-hydroxybutyl) nitrosamine

Table 1. Preclinical studies in different animal models of SBC with KLH or CCH as an immunotherapeutic agent. 
Later, the individual contributions of the $\mathrm{CCHA}$ and $\mathrm{CCHB}$ subunits of $\mathrm{CCH}$ as immunotherapeutic agents in the same bladder cancer model were studied. $\mathrm{C} 3 \mathrm{He} / \mathrm{He}$ mice were subcutaneously primed with $\mathrm{CCHA}$ or $\mathrm{CCHB}$; whole $\mathrm{CCH}$ and PBS were used as positive and negative controls, respectively. After day 15, mice were challenged with a subcutaneous injection of $2 \times 10^{5}$ MBT-2 cells, and the antitumor treatment was started; treatment consisted of a subcutaneous dose of either subunit or a control on alternate days for 9 days. Surprisingly, either subunit alone showed an antitumor effect in the MBT-2 model. However, the tumor incidence was lower in animals treated with CCHA (44\% incidence) than with $\mathrm{CCHB}$ (60\% incidence) or whole $\mathrm{CCH}(62.5 \%$ incidence). Moreover, the survival probability increased in mice under immunotherapy with CCHA (69.5\%) compared with CCHB- (64\%), CCH- (60\%) and PBS-treated (46.5\%) mice. In conclusion, this study indicated that the CCHA subunit accounts for the most important immunogenic effects of $\mathrm{CCH}$ (Becker et al., 2009). Together, these preclinical studies (summarized in Table 1) demonstrated that hemocyanins have beneficial effects in animal models of SBC that resemble human disease without the negative side effects of BCG (Schenkman \& Lamm, 2004).

\section{Use of hemocyanins in clinical studies of SBC}

Surgical procedures such as transurethral resection (TUR) are commonly used as the first option to treat SBC. However, there are some tumors that must be treated by other strategies, due to the difficulties of fully removing them and the high risk of recurrence. Thus, intravesical administration of chemotherapeutic and biological agents has been demonstrated to be an effective method in the early stages of the disease, either to treat an existing tumor or to prevent recurrence and tumor progression after TUR (Perabo \& Muller, 2004). BCG is one biological therapy that is used as a non-specific immunostimulant to treat several malignant tumors (Edwards \& Whitwell, 1974; Milas \& Withers, 1976), including SBC (Morales et al., 1976). BCG has become the first-line treatment and the most effective intravesical immunotherapy, lowering the risk of recurrence to an average of $27 \%$ of cases (Nseyo \& Lamm, 1997). Despite these successful results, BCG therapy causes numerous side effects, such as dysuria, urinary frequency, cystitis ( $90 \%$ of cases), hematuria and, in rare cases, sepsis, indicating the need for new approaches that provide the same or a better response without toxic effects (Lamm, 2003).

In a 1974 delayed-type hypersensitivity (DTH) experiment to measure the immune competence of patients with TCC, Olson and collaborators reported the unexpected result that patients subcutaneously primed with $5 \mathrm{mg}$ of $\mathrm{KLH}$ and then subcutaneous immunized with $200 \mu \mathrm{g}$ of KLH had a significantly diminished tumor recurrence rate over a study period of two years. Those patients that were DTH positive to KLH, and therefore immune competent, had almost no recurrences (Olsson et al., 1974). This outstanding effect was confirmed many years later in a controlled study of patients in stages Ta and T1 who had previously been subject to TUR. In this study, the ability of KLH to prevent tumor recurrence was compared to mitomycin $C$ (MMC). The patients were subcutaneously immunized with $1 \mathrm{mg}$ of KLH and then received monthly intravesical administrations of 10 mg of KLH. Only $14 \%$ of the patients treated with KLH had recurrences, in contrast to the MMC patients, 39\% of whom reported recurrences, demonstrating that KLH was significantly more effective than MMC (Jurincic et al., 1988). 
A prospective randomized trial compared the effects of ethoglucid and KLH in patients who were unresponsive to the chemotherapeutic treatments, doxorubicin or MMC. The recurrence rate and the tumor progression rate for the two therapies showed no statistical differences (Flamm et al., 1990). Wishahi et al., reported that the incidence of recurrence in patients with TCC associated with urinary schistosomiasis was 15\% after KLH treatment compared with $77 \%$ before therapy (Wishahi et al., 1995). This result was similar to the results obtained by Olson et al., (1974) and Jurincic et al., (1998) confirming the outstanding immunotherapeutic properties of KLH (Olsson et al., 1974; Jurincic et al., 1988). The efficacy of this treatment in patients with carcinoma in situ (CIS) grade 3 was studied in a long-term follow-up. The patients received an intravesical instillation of KLH weekly for 6 weeks, monthly for 1 year and bimonthly for the following 2 years. Patients who were unresponsive to KLH were treated with BCG. CIS long-term remission was observed only in a limited number of cases, and most cases progressed over time, indicating the aggressiveness of this disease (Jurincic-Winkler et al., 1995a). In Table 2, we summarize the clinical studies previously described.

Currently, Immucothel, a clinical-grade KLH preparation, is being evaluated in a Phase III clinical trial in Germany for its efficacy in SBC treatment (Biosyn). The Food and Drug Administration (FDA) has also authorized another Phase III trial to evaluate the efficacy and safety of KLH BCI-Immune Activator (Intracell, USA) versus doxorubicin in BCG refractory or intolerant patients with carcinoma in situ, with or without resected SBC. However, this study has been suspended.

The mechanism associated with the immunotherapeutic effect of KLH in this disease is still poorly understood. However, there are immunohistological studies on biopsies of TCC patients treated with KLH that show strong cellular activation characterized by the infiltration of large numbers of mononuclear cells and CD4+ lymphocytes, and to a lesser extent, CD8+ T cells and granulocytes, nine months after the beginning of therapy (JurincicWinkler et al., 1995b). This result suggests that the effect of KLH might be strongly related to a non-specific immunostimulation of the immune system leading to the development of an antitumor response.

\section{Immunologic mechanisms involved in the immunotherapy of SBC with hemocyanins}

Although hemocyanins are widely used as thymus-dependent model antigens, the relationship between the structure of hemocyanins and the molecular and cellular basis of their immunostimulatory capacity is still largely unknown. Investigations into the antitumor effect of hemocyanins in human and murine models of SBC have demonstrated a systemic activation of the immune response. In these experiments, priming with hemocyanins is crucial for the induction of antitumor activity (Lamm et al., 2000; Moltedo et al., 2006). This could partially explain why hemocyanins stimulate the immune system. In patients with TCC under intravesical KLH therapy, DTH reactions occur. As mentioned previously, studies on biopsies of TCC patients treated with KLH showed a higher increase in CD4+ cell infiltration than CD8+ T lymphocytes in the submucosa and urothelial cells (JurincicWinkler et al., 1995b). Currently, we know that such responses are characteristic of Th1 type responses, which mediate inflammatory functions critical for the development of cell- 
mediated immune responses (Szabo et al., 2003). Other investigations demonstrated that during immunization with $\mathrm{KLH}$, the T CD4+ lymphocyte response showed a mixed profile of IL-4 and IFN- $\gamma$ with an increase in T CD8+ cells in the lymphatic nodules (Doyle et al., 1998).

\begin{tabular}{|c|c|c|c|c|c|}
\hline Patients & $\begin{array}{l}\text { Control } \\
\text { Group }\end{array}$ & Priming & $\begin{array}{l}\text { Therapeutic } \\
\text { Dosage and } \\
\text { Schedule }\end{array}$ & $\begin{array}{l}\text { Recurrence } \\
\text { Rate }\end{array}$ & Reference \\
\hline 19 & 10 & $\begin{array}{l}5 \mathrm{mg} \\
\text { subcutaneous }\end{array}$ & $\begin{array}{l}200 \mu \mathrm{g} \\
\text { Subcutaneous }\end{array}$ & $11 \%$ & $\begin{array}{l}\text { Olsson } \\
\text { et al. } 1974\end{array}$ \\
\hline 44 & 23 & $\begin{array}{l}1 \mathrm{mg} \\
\text { subcutaneous }\end{array}$ & $\begin{array}{l}10 \mathrm{mg} \\
\text { Intravesical, } \\
\text { monthly for } 21 \\
\text { months, } \\
\text { approximately. }\end{array}$ & $14 \%$ & $\begin{array}{l}\text { Jurincic } \\
\text { et al. } 1988\end{array}$ \\
\hline 84 & 46 & $\begin{array}{l}1 \mathrm{mg} \\
\text { subcutaneous }\end{array}$ & $\begin{array}{l}30 \mathrm{mg} \\
\text { Intravesical, } \\
\text { weekly for six } \\
\text { weeks and then } \\
\text { monthly for one } \\
\text { year. }\end{array}$ & $55 \%$ & $\begin{array}{l}\text { Flamm } \\
\text { et al. } 1990\end{array}$ \\
\hline 13 & $\begin{array}{l}\text { Own } \\
\text { controls }\end{array}$ & $\begin{array}{l}1 \mathrm{mg} \\
\text { subcutaneous } \\
\text { for five days } \\
\text { until DTH }\end{array}$ & $\begin{array}{l}10 \mathrm{mg} \\
\text { Intravesical, for } \\
\text { seven days. }\end{array}$ & $15 \%$ & $\begin{array}{l}\text { Wishashi } \\
\text { et al. } 1995\end{array}$ \\
\hline 21 & $\begin{array}{l}\text { Own } \\
\text { controls }\end{array}$ & No & $\begin{array}{l}20 \mathrm{mg} \\
\text { Intravesical, } \\
\text { weekly for six } \\
\text { weeks and then } \\
\text { monthly for one } \\
\text { year or bimonthly } \\
\text { for two years. }\end{array}$ & $\begin{array}{l}43 \% \text { of patients } \\
\text { presented long- } \\
\text { term remission } \\
57 \% \text { had to be } \\
\text { cystectomized } \\
\text { because of CIS } \\
\text { progression }\end{array}$ & $\begin{array}{l}\text { Jurincic- } \\
\text { Winkler } \\
\text { et al. 1995a }\end{array}$ \\
\hline
\end{tabular}

Table 2. Clinical studies using KLH as an immunotherapeutic agent in SBC patients.

The fact that the non-specific immunotherapeutic effects of hemocyanins are not due to any super-antigen-like activity, but rather rely on adequate priming, strongly suggests that their therapeutic properties could be attributable to a bystander effect on the tumor due to either a loss of tolerance toward tumor antigens or an enhancement of the immune response to the tumor. This kind of response would favor a milieu that augments the antigen-specific activity of cytotoxic T lymphocytes (CTLs) and natural killer (NK) cell responses. These hypotheses are supported by the observation that IFN- $\gamma$ and IL-2 are secreted in the regional lymph nodes in response to hemocyanin treatment (Gilliet et al., 2003; Verdijk et al., 2009). NK cells are strongly stimulated by IL-2 secreted by T lymphocytes, leading to their differentiation into lymphokine-activated killer cells (LAK) and increasing the destructive elements acting on tumor cells. It has been reported that 
MBT-2 cells do not grow when they are injected into the bladders of mice treated with a combination of IL-2 and the cytotoxic agent cyclophosphamide (Ikemoto et al., 1997). Moreover, KLH has been shown to enhance NK cell activity and stimulate IFN- $\gamma$ secretion in SBC patients (Molto et al., 1991). Our later results confirm these observations; mice treated with KLH or CCH increase NK cell activity and serum levels of IFN- $\gamma$ (Moltedo et al., 2006). This is a very important result because, in primary tumors, IFN- $\gamma$ is a tumor suppressor cytokine that coordinates T and NK cell activities (Kaplan et al., 1998). Indeed, it has been demonstrated that the depletion of NK cells abolishes the immunotherapeutic effect of BCG on bladder cancer in mice, confirming that these cells play a key role in the destruction of primary tumors (Brandau \& Bohle, 2001).

In addition to the antitumor effect provided by the secretion of IFN- $\gamma$, NK cells can delay tumor growth by means of antibody-dependent cell-mediated cytotoxicity (ADCC), which induces effector cells to kill bladder tumor target cells. We have observed that, in the MBT-2 model, intralesional $\mathrm{CCH}$ or $\mathrm{KLH}$ induce an increase in the humoral immune response against cell surface tumor antigens in addition to the $\mathrm{CCH}$ or KLH antibody response. Biopsies taken from the surrounding bladder tissues in SBC patients treated with KLH showed an increase in the B lymphocyte population in the lymph follicles, suggesting that humoral mechanism are also involved in the immune response induced by hemocyanins (Jurincic-Winkler et al., 1995b).

Finally, the fact that the immunotherapeutic effects of $\mathrm{KLH}$ and $\mathrm{CCH}$ on bladder cancer do not require an adjuvant raises intriguing questions regarding the means by which hemocyanins initiate the non-specific anti-tumor immune response and which cells are involved. It is possible that hemocyanins interact with a putative receptor on the cell surface of antigen presenting cells, leading to their internalization and processing. A promising candidate was the mannose receptor because of the high levels of this sugar residue in KLH and $\mathrm{CCH}$ and the fact that this receptor is highly expressed in antigen presenting cells. However, experiments on endocytosis inhibition performed in human DCs cultured in vitro with an anti-mannose receptor antibody and KLH showed that while KLH incorporation by DCs was partially inhibited, KLH still promoted the activation and maturation of DCs as assessed by the up-regulation of the cell surface expression of Major Histocompatibility Complex (MHC) class II and co-stimulatory molecules (Presicce et al., 2008). In contrast, Teitz-Tennenbaum and collaborators (2008) demonstrated that murine DCs pulsed with KLH for 18 hours in vitro did not undergo DC maturation, a result that is consistent with in vivo experiments (Teitz-Tennenbaum et al., 2008; Moltedo et al., 2009) and our current results. We observed that DCs internalized (Fig. 3) but did not mature within 72 hours of culture in vitro with this protein

It is not known whether hemocyanins might be processed and presented by bladder tumor cells themselves, leading to the stimulation of the cytotoxic killer cell antitumor activity. Murine bladder tumor cells have been shown to be able to present BCG antigens to specific CD4+ T lymphocytes in a classic MHC Class II (Ia)-dependent fashion (Lattime et al., 1992). Experiments performed in our laboratory demonstrated that primary cultures of mouse bladder epithelial cells and MBT-2 cells cultured in vitro incorporate hemocyanin; however, we did not observe any changes in the expression pattern of MHC I and MHC II antigens (Del Campo et al., 2007). In addition, in vitro anti-cancer effects of KLH against breast, esophageal, prostate and pancreas cancer has been reported (Riggs et al., 2002), also in melanoma (Somasundar et al., 2005), however if this effect have an in vivo implication is unknown. 

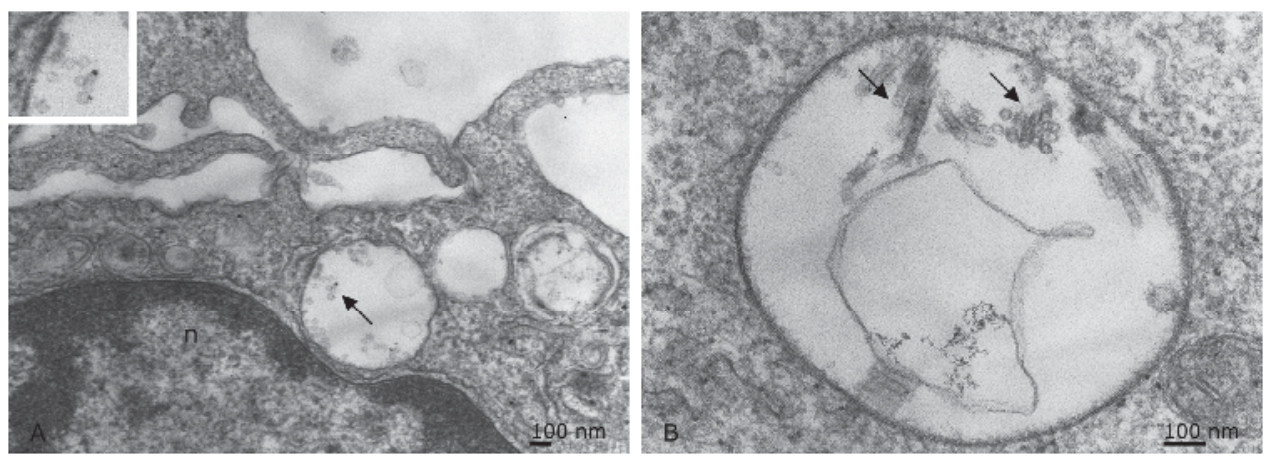

Fig. 3. Incorporation of Concholepas hemocyanin by mouse myeloid dendritic cells cultured in vitro, analyzed by transmission electron microscopy. Mouse myeloid DCs of 5th day of culture in vitro as described (Inaba et al., 1992), previously isolated by positive selection with immunomagnetic beads, and later culture with $\mathrm{CCH}$ during different times. A. Dendritic cell cultured during 30 minutes with $\mathrm{CCH}$. The photograph shows its characteristic superficial membrane process, the nucleus (n), and hemocyanin molecules inside a clear vacuole (arrow) that resemble a primary lysosome. B. Because of the large size of $\mathrm{CCH}$, and because of its peculiar structure as a hollow cylinder, we were able to identify the presence of whole hemocyanin molecules inside secondary lysosome like vesicles (arrows) containing membrane debris (Del Campo et al., 2007).

Macrophages are another potential cell type through which hemocyanins could initiate antitumor immune responses. Indeed, IL-1 $\alpha$, a pro-inflammatory cytokine produced by activated macrophages, has been shown to be increased in the urine after intravesical instillation with KLH in patients with SBC (Jurincic-Winkler et al., 1995c). Similarly, this cytokine, in addition to other pro-inflammatory cytokines, has been detected in the urine after BCG instillation along with an influx of mononuclear cells into the bladder (Teppema et al., 1992; Brandau \& Bohle, 2001; Brandau et al., 2001).

In summary, considering that BCG is a whole organism, whereas $\mathrm{KLH}$ or CCH are single molecules, it is amazing that it induces a similar response. In both cases, however, it is not clear which cytokines and cells contribute directly to the anti-tumor activity and which represent a secondary phenomenon.

\section{Conclusions}

Hemocyanins have proven to be safe and useful in the immunotherapy and prophylaxis of patients with superficial bladder cancer who have failed or are intolerant to the current BCG therapy. Moreover, KLH has been shown to produce a more predictable reaction than BCG, eliminating the risk of further infections. Despite the fact that biomedical interest in mollusk hemocyanins goes back more than 40 years, the precise molecular and cellular mechanisms underlying the non-specific immunostimulatory capacities of KLH and, more recently, $\mathrm{CCH}$, are poorly understood. The current evidence shows that these huge proteins can induce an inflammatory milieu and activate innate immunity, driving a vigorous antitumor 
adaptive immune response characterized by long-lasting HLA-DR+ cell infiltration into the bladder and the secretion of a Th1-type cytokine profile.

\section{Acknowledgments}

We thank Alfredo De Ioannes, Cristóbal Dünner and Augusto Manubens (Biosonda Corporation) and Miguel Del Campo, Pablo De Ioannes and Bruno Moltedo (Fundación Ciencia y Tecnología para el Desarrollo, FUCITED) for their valuable discussions during the course of this work. The authors are grateful to Gabriel De Ioannes for the mollusk hemocyanin structure model.

This study was partially supported by FONDECYT grant 1110651 (to María Inés Becker). Sergio Arancibia is a CONICYT (National Commission for Sciences and Technology of Chile) doctoral fellow.

\section{References}

Altenhein, B., Markl, J. \& Lieb, B. (2002). Gene structure and hemocyanin isoform HtH2 from the mollusc Haliotis tuberculata indicate early and late intron hot spots. Gene, Vol.301, No.1-2: pp. 53-60, 0378-1119

Arancibia, S., Espinoza, C., Del Campo, M., Salazar, F. \& Becker, M.I. (2010). Exceptional immunological and anticancer properties of a new hemocyanin from Fissurella Latimarginata (FLH). Proceedings of International Society for Biological Therapy of Cancer. Washington, USA. October, 2010

Arentsen, H.C., Hendricksen, K., Oosterwijk, E. \& Witjes, J.A. (2009). Experimental rat bladder urothelial cell carcinoma models. World J Urol, Vol.27, No.3: pp. 313-317, 1433-8726

Atala, A. (2006). This month in investigative urology. J Urol 2006. J Urol, Vol.176, No.6 Pt 1: pp. 2335-2336, 0022-5347

Becker, M.I., Carrasco, I., Beltran, C., Torres, M., Jaureguiberry, B. \& De Ioannes, A.E. (1998). Development of monoclonal antibodies to gizzerosine, a toxic component present in fish meal. Hybridoma, Vol.17, No.4: pp. 373-381, 0272-457X

Becker, M.I., De Ioannes, A.E., Leon, C. \& Ebensperger, L.A. (2007). Females of the communally breeding rodent, Octodon degus, transfer antibodies to their offspring during pregnancy and lactation. J Reprod Immunol, Vol.74, No.1-2: pp. 68-77, 01650378

Becker, M.I., Fuentes, A., Del Campo, M., Manubens, A., Nova, E., Oliva, H., Faunes, F., Valenzuela, M.A., Campos-Vallette, M., Aliaga, A., Ferreira, J., De Ioannes, A.E., De Ioannes, P. \& Moltedo, B. (2009). Immunodominant role of CCHA subunit of Concholepas hemocyanin is associated with unique biochemical properties. Int Immunopharmacol, Vol.9, No.3: pp. 330-339, 1878-1705

Biosyn. In: Vacmune Immucothel, July 2011, Available from: http://www.biosyncorp.com/bc_downloads/vacmune.pdf.

Brandau, S. \& Bohle, A. (2001). Activation of natural killer cells by Bacillus Calmette-Guerin. Eur Urol, Vol.39, No.5: pp. 518-524, 0302-2838

Brandau, S., Riemensberger, J., Jacobsen, M., Kemp, D., Zhao, W., Zhao, X., Jocham, D., Ratliff, T.L. \& Bohle, A. (2001). NK cells are essential for effective BCG immunotherapy. Int J Cancer, Vol.92, No.5: pp. 697-702, 0020-7136 
Cancino, J., Torrealba, C., Soza, A., Yuseff, M.I., Gravotta, D., Henklein, P., RodriguezBoulan, E. \& Gonzalez, A. (2007). Antibody to AP1B adaptor blocks biosynthetic and recycling routes of basolateral proteins at recycling endosomes. Mol Biol Cell, Vol.18, No.12: pp. 4872-4884, 1059-1524

Cuff, M.E., Miller, K.I., van Holde, K.E. \& Hendrickson, W.A. (1998). Crystal structure of a functional unit from Octopus hemocyanin. J Mol Biol, Vol.278, No.4: pp. 855-870, 0022-2836

De Ioannes, P., Moltedo, B., Oliva, H., Pacheco, R., Faunes, F., De Ioannes, A.E. \& Becker, M.I. (2004). Hemocyanin of the molluscan Concholepas concholepas exhibits an unusual heterodecameric array of subunits. J Biol Chem, Vol.279, No.25: pp. 2613426142, 0021-9258

Decker, H. \& Tuczek, F. (2000). Tyrosinase/catecholoxidase activity of hemocyanins: structural basis and molecular mechanism. Trends Biochem Sci, Vol.25, No.8: pp. 392-397, 0968-0004

Decker, H., Hellmann, N., Jaenicke, E., Lieb, B., Meissner, U. \& Markl, J. (2007). Minireview: Recent progress in hemocyanin research. Integr Comp Biol, Vol.47, No.4: pp. 631-644, 1540-7063

Del Campo, M., Lagos, L., Manubens, A., Ioannes, A., Moltedo, B. \& Becker, M.I. (2007). Efecto de la hemocianina de C. Concholepas $(\mathrm{CCH})$ en la maduración de células dendríticas. Proceedings of XXX Reunión Anual de la Sociedad de Bioquímica y Biología Molecular de Chile. Chillán, Chile. September, 2007.

Del Campo, M., Arancibia, S., Nova, E., Salazar, F., Gonzalez, A., Moltedo, B., De Ioannes, P., Ferreira, J., Manubens, A. \& Becker, M.I. (2011). Hemocyanins as immunostimulants. Rev. méd. Chile, Vol.139, No.2: pp. 236-246

Dolashka-Angelova, P., Beck, A., Dolashki, A., Beltramini, M., Stevanovic, S., Salvato, B. \& Voelter, W. (2003). Characterization of the carbohydrate moieties of the functional unit RvH1-a of Rapana venosa haemocyanin using HPLC/electrospray ionization MS and glycosidase digestion. Biochem J, Vol.374, No.Pt 1: pp. 185-192, 0264-6021

Dolashka-Angelova, P., Stefanova, T., Livaniou, E., Velkova, L., Klimentzou, P., Stevanovic, S., Salvato, B., Neychev, H. \& Voelter, W. (2008). Immunological potential of Helix vulgaris and Rapana venosa hemocyanins. Immunol Invest, Vol.37, No.8: pp. 822-840, 1532-4311

Dolashka, P., Velkova, L., Shishkov, S., Kostova, K., Dolashki, A., Dimitrov, I., Atanasov, B., Devreese, B., Voelter, W. \& Van Beeumen, J. (2010). Glycan structures and antiviral effect of the structural subunit RvH2 of Rapana hemocyanin. Carbohydr Res, Vol.345, No.16: pp. 2361-2367, 1873-426X

Doyle, A.G., Ramm, L. \& Kelso, A. (1998). The CD4+ T-cell response to protein immunization is independent of accompanying IFN-gamma-producing CD8+ T cells. Immunology, Vol.93, No.3: pp. 341-349, 0019-2805

Duvillie, B., Attali, M., Aiello, V., Quemeneur, E. \& Scharfmann, R. (2003). Label-retaining cells in the rat pancreas: location and differentiation potential in vitro. Diabetes, Vol.52, No.8: pp. 2035-2042, 0012-1797

Edwards, F.R. \& Whitwell, F. (1974). Use of BCG as an immunostimulant in the surgical treatment of carcinoma of the lung. Thorax, Vol.29, No.6: pp. 654-658, 0040-6376

Espinoza, C., De Ioannes, A.E. \& Becker, M.I. (2006). Caracterización bioquímica e inmunoquímica de la hemocianina de tres especies de lapas chilenas de la Familia 
Fissurellidae. Proceedings of XXIX Reunión Anual de la Sociedad de Bioquímica y Biología Molecular de Chile. Pucón, Chile. November, 2006.

FDA. In: ClinicalTrials.gov, July 2011, Available from: http://clinicaltrials.gov/ct2/results?tem=KLH

Flamm, J., Bucher, A., Holtl, W. \& Albrecht, W. (1990). Recurrent superficial transitional cell carcinoma of the bladder: adjuvant topical chemotherapy versus immunotherapy. A prospective randomized trial. J Urol, Vol.144, No.2 Pt 1: pp. 260-263, 0022-5347

Gatsogiannis, C. \& Markl, J. (2009). Keyhole limpet hemocyanin: 9-A CryoEM structure and molecular model of the KLH1 didecamer reveal the interfaces and intricate topology of the 160 functional units. J Mol Biol, Vol.385, No.3: pp. 963-983, 10898638

Ghiretti-Magaldi, A. \& Ghiretti, F. (1992). The pre-history of hemocyanin. The discovery of copper in the blood of molluscs. Experientia, Vol.48: pp. 971-972

Gielens, C., De Geest, N., Compernolle, F. \& Preaux, G. (2004). Glycosylation sites of hemocyanins of Helix pomatia and Sepia officinalis. Micron, Vol.35, No.1-2: pp. 99-100, 0968-4328

Gilliet, M., Kleinhans, M., Lantelme, E., Schadendorf, D., Burg, G. \& Nestle, F.O. (2003). Intranodal injection of semimature monocyte-derived dendritic cells induces $\mathrm{T}$ helper type 1 responses to protein neoantigen. Blood, Vol.102, No.1: pp. 36-42, 00064971

Gravotta, D., Deora, A., Perret, E., Oyanadel, C., Soza, A., Schreiner, R., Gonzalez, A. \& Rodriguez-Boulan, E. (2007). AP1B sorts basolateral proteins in recycling and biosynthetic routes of MDCK cells. Proc Natl Acad Sci U S A, Vol.104, No.5: pp. 1564-1569, 0027-8424

Grenegard, M., Vretenbrant-Oberg, K., Nylander, M., Desilets, S., Lindstrom, E.G., Larsson, A., Ramstrom, I., Ramstrom, S. \& Lindahl, T.L. (2008). The ATP-gated P2X1 receptor plays a pivotal role in activation of aspirin-treated platelets by thrombin and epinephrine. J Biol Chem, Vol.283, No.27: pp. 18493-18504, 0021-9258

Gunther, J.H., Jurczok, A., Wulf, T., Brandau, S., Deinert, I., Jocham, D. \& Bohle, A. (1999). Optimizing syngeneic orthotopic murine bladder cancer (MB49). Cancer Res, Vol.59, No.12: pp. 2834-2837, 0008-5472

Harris, J.R., Gebauer, W. \& Markl, J. (1993). Immunoelectron Microscopy od Hemocyanin from the Keyhole Limpet (Megathura crenulata): A Parallel Subunit Model. J Struct Biol, Vol.111: pp. 96-104

Harris, J.R. \& Markl, J. (1999). Keyhole limpet hemocyanin (KLH): a biomedical review. Micron, Vol.30, No.6: pp. 597-623, 0968-4328

Idakieva, K., Stoeva, S., Voelter, W. \& Gielens, C. (2004). Glycosylation of Rapana thomasiana hemocyanin. Comparison with other prosobranch (gastropod) hemocyanins. Comp Biochem Physiol B Biochem Mol Biol, Vol.138, No.3: pp. 221-228, 1096-4959

Ikemoto, S., Kamizuru, M., Wada, S., Asai, Y. \& Kishimoto, T. (1997). Changes in lymphocyte subsets following administration of interleukin 2 and cyclophosphamide in mice with transitional cell carcinoma. Oncol Res, Vol.9, No.2: pp. 71-75, 0965-0407

Inaba, K., Inaba, M., Romani, N., Aya, H., Deguchi, M., Ikehara, S., Muramatsu, S. \& Steinman, R.M. (1992). Generation of large numbers of dendritic cells from mouse 
bone marrow cultures supplemented with granulocyte/macrophage colonystimulating factor. J Exp Med, Vol.176, No.6: pp. 1693-1702, 0022-1007

Jacobs, J.F., Punt, C.J., Lesterhuis, W.J., Sutmuller, R.P., Brouwer, H.M., Scharenborg, N.M., Klasen, I.S., Hilbrands, L.B., Figdor, C.G., de Vries, I.J. \& Adema, G.J. (2010). Dendritic cell vaccination in combination with anti-CD25 monoclonal antibody treatment: a phase I/II study in metastatic melanoma patients. Clin Cancer Res, Vol.16, No.20: pp. 5067-5078, 1078-0432

Jurincic-Winkler, C., Metz, K.A., Beuth, J., Sippel, J. \& Klippel, K.F. (1995a). Effect of keyhole limpet hemocyanin (KLH) and bacillus Calmette-Guerin (BCG) instillation on carcinoma in situ of the urinary bladder. Anticancer Res, Vol.15, No.6B: pp. 27712776, 0250-7005

Jurincic-Winkler, C., Metz, K.A., Beuth, J., Engelmann, U. \& Klippel, K.F. (1995b). Immunohistological findings in patients with superficial bladder carcinoma after intravesical instillation of keyhole limpet haemocyanin. Br J Urol, Vol.76, No.6: pp. 702-707, 0007-1331

Jurincic-Winkler, C.D., Gallati, H., Alvarez-Mon, M., Sippel, J., Carballido, J. \& Klippel, K.F. (1995c). Urinary interleukin-1 alpha levels are increased by intravesical instillation with keyhole limpet hemocyanin in patients with superficial transitional cell carcinoma of the bladder. Eur Urol, Vol.28, No.4: pp. 334-339, 0302-2838

Jurincic, C.D., Engelmann, U., Gasch, J. \& Klippel, K.F. (1988). Immunotherapy in bladder cancer with keyhole-limpet hemocyanin: a randomized study. J Urol, Vol.139, No.4: pp. 723-726, 0022-5347

Kafi, K., Betting, D.J., Yamada, R.E., Bacica, M., Steward, K.K. \& Timmerman, J.M. (2009). Maleimide conjugation markedly enhances the immunogenicity of both human and murine idiotype-KLH vaccines. Mol Immunol, Vol.46, No.3: pp. 448-456, 0161-5890

Kaplan, D.H., Shankaran, V., Dighe, A.S., Stockert, E., Aguet, M., Old, L.J. \& Schreiber, R.D. (1998). Demonstration of an interferon gamma-dependent tumor surveillance system in immunocompetent mice. Proc Natl Acad Sci U S A, Vol.95, No.13: pp. 7556-7561, 0027-8424

Lamm, D.L., Reyna, J.A. \& Reichert, D.F. (1981). Keyhole-limpet haemacyanin and immune ribonucleic acid immunotherapy of murine transitional cell carcinoma. Urol Res, Vol.9, No.5: pp. 227-230, 0300-5623

Lamm, D.L., Reichert, D.F., Harris, S.C. \& Lucio, R.M. (1982). Immunotherapy of murine transitional cell carcinoma. J Urol, Vol.128, No.5: pp. 1104-1108, 0022-5347

Lamm, D.L., DeHaven, J.I., Riggs, D.R. \& Ebert, R.F. (1993a). Immunotherapy of murine bladder cancer with keyhole limpet hemocyanin (KLH). J Urol, Vol.149, No.3: pp. 648-652, 0022-5347

Lamm, D.L., DeHaven, J.I., Riggs, D.R., Delgra, C. \& Burrell, R. (1993b). Keyhole limpet hemocyanin immunotherapy of murine bladder cancer. Urol Res, Vol.21, No.1: pp. 33-37, 0300-5623

Lamm, D.L., Dehaven, J.I. \& Riggs, D.R. (2000). Keyhole limpet hemocyanin immunotherapy of bladder cancer: laboratory and clinical studies. Eur Urol, Vol.37 Suppl 3: pp. 41-44, 0302-2838

Lamm, D.L. (2003). Laboratory and Clinical Experience with Keyhole limpet hemocyanin (Immunocothel) in superficial bladder cancer. J. Urol., Vol.10, No.2: pp. 18-21 
Lattime, E.C., Gomella, L.G. \& McCue, P.A. (1992). Murine bladder carcinoma cells present antigen to BCG-specific CD4+ T-cells. Cancer Res, Vol.52, No.15: pp. 4286-4290, 0008-5472

Lau, B.H., Woolley, J.L., Marsh, C.L., Barker, G.R., Koobs, D.H. \& Torrey, R.R. (1986). Superiority of intralesional immunotherapy with Corynebacterium paroum and Allium sativum in control of murine transitional cell carcinoma. J Urol, Vol.136, No.3: pp. 701-705, 0022-5347

Leitch, H.A. \& Connors, J.M. (2005). Vaccine therapy for non-Hodgkin's lymphoma and other B-cell malignancies. Curr Opin Investig Drugs, Vol.6, No.6: pp. 597-604, 14724472

Lesterhuis, W.J., Schreibelt, G., Scharenborg, N.M., Brouwer, H.M., Gerritsen, M.J., Croockewit, S., Coulie, P.G., Torensma, R., Adema, G.J., Figdor, C.G., de Vries, I.J. \& Punt, C.J. (2011). Wild-type and modified gp100 peptide-pulsed dendritic cell vaccination of advanced melanoma patients can lead to long-term clinical responses independent of the peptide used. Cancer Immunol Immunother, Vol.60, No.2: pp. 249-260, 1432-0851

Leyton, P., Lizama-Vergara, P.A., Campos-Vallete, M.M., Becker, M.I., Clavijo, E., Cordova Reyes, I., Vera, M. \& Jerez, C.A. (2005). Surface enhanced Raman spectrum of nanometric molecular systems. J. Chile. Chem. Soc., Vol.50, No.4: pp. 725-730, 07179707

Lieb, B., Altenhein, B., Markl, J., Vincent, A., van Olden, E., van Holde, K.E. \& Miller, K.I. (2001). Structures of two molluscan hemocyanin genes: significance for gene evolution. Proc Natl Acad Sci U S A, Vol.98, No.8: pp. 4546-4551, 0027-8424

Linn, J.F., Black, P., Derksen, K., Rubben, H. \& Thuroff, J.W. (2000). Keyhole limpet haemocyanin in experimental bladder cancer: literature review and own results. Eur Urol, Vol.37 Suppl 3: pp. 34-40, 0302-2838

Lommerse, J.P., Thomas-Oates, J.E., Gielens, C., Preaux, G., Kamerling, J.P. \& Vliegenthart, J.F. (1997). Primary structure of 21 novel monoantennary and diantennary N-linked carbohydrate chains from alphaD-hemocyanin of Helix pomatia. Eur J Biochem, Vol.249, No.1: pp. 195-222, 0014-2956

Lopez, M.N., Pereda, C., Segal, G., Munoz, L., Aguilera, R., Gonzalez, F.E., Escobar, A., Ginesta, A., Reyes, D., Gonzalez, R., Mendoza-Naranjo, A., Larrondo, M., Compan, A., Ferrada, C. \& Salazar-Onfray, F. (2009). Prolonged survival of dendritic cellvaccinated melanoma patients correlates with tumor-specific delayed type IV hypersensitivity response and reduction of tumor growth factor beta-expressing $\mathrm{T}$ cells. J Clin Oncol, Vol.27, No.6: pp. 945-952, 1527-7755

Manosalva, H., De Ioannes, A.E. \& Becker, M.I. (2004). Development of monoclonal antibodies bearing the internal image of the gizzerosine epitope and application in a competitive ELISA for fish meal. Hybrid Hybridomics, Vol.23, No.1: pp. 45-54, 1536-8599

Manubens, A., Salazar, F., Haussmann, D., Figueroa, J., Del Campo, M., Pinto, J.M., Huaquin, L., Venegas, A. \& Becker, M.I. (2010). Concholepas hemocyanin biosynthesis takes place in the hepatopancreas, with hemocytes being involved in its metabolism. Cell Tissue Res, Vol.342, No.3: pp. 423-435, 1432-0878 
Markl, J., Lieb, B., Gebauer, W., Altenhein, B., Meissner, U. \& Harris, J.R. (2001). Marine tumor vaccine carriers: structure of the molluscan hemocyanins KLH and HtH. J Cancer Res Clin Oncol, Vol.127 Suppl 2: pp. R3-9, 0171-5216

Marsh, C.L., Torrey, R.R., Woolley, J.L., Barker, G.R. \& Lau, B.H. (1987). Superiority of intravesical immunotherapy with Corynebacterium paroum and Allium sativum in control of murine bladder cancer. J Urol, Vol.137, No.2: pp. 359-362, 0022-5347

Matus, S., Burgos, P.V., Bravo-Zehnder, M., Kraft, R., Porras, O.H., Farias, P., Barros, L.F., Torrealba, F., Massardo, L., Jacobelli, S. \& Gonzalez, A. (2007). Antiribosomal-P autoantibodies from psychiatric lupus target a novel neuronal surface protein causing calcium influx and apoptosis. J Exp Med, Vol.204, No.13: pp. 3221-3234, 1540-9538

Mauldin, R.E. \& Miller, L.A. (2007). Wildlife contraception: targeting the oocyte. Managing Vertebrate Invasive Species: Proceedings of an International Symposium. G.W. Witmer, W.C. Pitt\&K.A. Fagerstone. National Wildlife Research Center, Fort Collins, CO.

Milas, L. \& Withers, H.R. (1976). Nonspecific immunotherapy of malignant tumors. Radiology, Vol.118, No.1: pp. 211-218, 0033-8419

Millard, A.L., Ittelet, D., Schooneman, F. \& Bernard, J. (2003). Dendritic cell KLH loading requirements for efficient $\mathrm{CD} 4+\mathrm{T}$-cell priming and help to peptide-specific cytotoxic T-cell response, in view of potential use in cancer vaccines. Vaccine, Vol.21, No.9-10: pp. 869-876, 0264-410X

Miller, L.A., Talwar, G.P. \& Killian, G.J. (2006). Contraceptive effect of a recombinant GnRH vaccine in adult female pigs. Proc. 22nd Vertebr. Pest. Conf. O.B.J. Timm RM, Univ. of Calif: pp. 106-109.

Moltedo, B., Faunes, F., Haussmann, D., De Ioannes, P., De Ioannes, A.E., Puente, J. \& Becker, M.I. (2006). Immunotherapeutic effect of Concholepas hemocyanin in the murine bladder cancer model: evidence for conserved antitumor properties among hemocyanins. J Urol, Vol.176, No.6 Pt 1: pp. 2690-2695, 0022-5347

Moltedo, B., Lopez, C.B., Pazos, M., Becker, M.I., Hermesh, T. \& Moran, T.M. (2009). Cutting edge: stealth influenza virus replication precedes the initiation of adaptive immunity. J Immunol, Vol.183, No.6: pp. 3569-3573, 1550-6606

Molto, L.M., Carballido, J., Jurincic, C., Lapena, P., Manzano, L., Salmeron, I., Klippel, K.F. \& Alvarez-Mon, M. (1991). Keyhole limpet hemocyanine can enhance the natural killer activity of patients with transitional cell carcinoma of the bladder. Eur Urol, Vol.19, No.1: pp. 74-78, 0302-2838

Morales, A., Eidinger, D. \& Bruce, A.W. (1976). Intracavitary Bacillus Calmette-Guerin in the treatment of superficial bladder tumors. J Urol, Vol.116, No.2: pp. 180-183, 00225347

Mura, C.V., Becker, M.I., Orellana, A. \& Wolff, D. (2002). Immunopurification of Golgi vesicles by magnetic sorting. J Immunol Methods, Vol.260, No.1-2: pp. 263-271, 00221759

Musselli, C., Livingston, P.O. \& Ragupathi, G. (2001). Keyhole limpet hemocyanin conjugate vaccines against cancer: the Memorial Sloan Kettering experience. J Cancer Res Clin Oncol, Vol.127 Suppl 2: pp. R20-26, 0171-5216

Nseyo, U.O. \& Lamm, D.L. (1997). Immunotherapy of bladder cancer. Semin Surg Oncol, Vol.13, No.5: pp. 342-349, 8756-0437 
Oliva, H., Moltedo, B., De Ioannes, P., Faunes, F., De Ioannes, A.E. \& Becker, M.I. (2002). Monoclonal antibodies to molluskan hemocyanin from Concholepas concholepas demonstrate common and specific epitopes among subunits. Hybrid Hybridomics, Vol.21, No.5: pp. 365-374, 1536-8599

Olsson, C.A., Chute, R. \& Rao, C.N. (1974). Immunologic reduction of bladder cancer recurrence rate. J Urol, Vol.111, No.2: pp. 173-176, 0022-5347

Orlova, E.V., Dube, P., Harris, J.R., Beckman, E., Zemlin, F., Markl, J. \& van Heel, M. (1997). Structure of keyhole limpet hemocyanin type 1 (KLH1) at 15 A resolution by electron cryomicroscopy and angular reconstitution. J Mol Biol, Vol.271, No.3: pp. 417-437, 0022-2836

Paccagnella, M., Bologna, L., Beccaro, M., Micetic, I., Di Muro, P. \& Salvato, B. (2004). Structural subunit organization of molluscan hemocyanins. Micron, Vol.35, No.1-2: pp. 21-22, 0968-4328

Perabo, F.G. \& Muller, S.C. (2004). Current and new strategies in immunotherapy for superficial bladder cancer. Urology, Vol.64, No.3: pp. 409-421, 1527-9995

Pilon, J., Loiacono, C., Okeson, D., Lund, S., Vercauteren, K., Rhyan, J. \& Miller, L. (2007). Anti-prion activity generated by a novel vaccine formulation. Neurosci Lett, Vol.429, No.2-3: pp. 161-164, 0304-3940

Presicce, P., Taddeo, A., Conti, A., Villa, M.L. \& Della Bella, S. (2008). Keyhole limpet hemocyanin induces the activation and maturation of human dendritic cells through the involvement of mannose receptor. Mol Immunol, Vol.45, No.4: pp. 1136$1145,0161-5890$

Recker, F. \& Rubben, H. (1989). Variation of the immunosystem by ciclosporin and keyholelimpet hemocyanin--are there effects on chemically induced bladder carcinoma? Urol Int, Vol.44, No.2: pp. 77-80, 0042-1138

Riggs, D.R., Tarry, W.F., DeHaven, J.I., Sosnowski, J. \& Lamm, D.L. (1992). Immunotherapy of murine transitional cell carcinoma of the bladder using alpha and gamma interferon in combination with other forms of immunotherapy. J Urol, Vol.147, No.1: pp. 212-214, 0022-5347

Riggs, D.R., Jackson, B., Vona-Davis, L. \& McFadden, D. (2002). In vitro anticancer effects of a novel immunostimulant: keyhole limpet hemocyanin. J Surg Res, Vol.108, No.2: pp. 279-284, 0022-4804

Schenkman, E. \& Lamm, D.L. (2004). Superficial bladder cancer therapy. ScientificWorldJournal, Vol.4 Suppl 1: pp. 387-399, 1537-744X

Schumacher, K. (2001). Keyhole limpet hemocyanin (KLH) conjugate vaccines as novel therapeutic tools in malignant disorders. J Cancer Res Clin Oncol, Vol.127 Suppl 2: pp. R1-2, 0171-5216

Shimizu, K., Thomas, E.K., Giedlin, M. \& Mule, J.J. (2001). Enhancement of tumor lysateand peptide-pulsed dendritic cell-based vaccines by the addition of foreign helper protein. Cancer Res, Vol.61, No.6: pp. 2618-2624, 0008-5472

Siddiqui, N.I., Idakieva, K., Demarsin, B., Doumanova, L., Compernolle, F. \& Gielens, C. (2007). Involvement of glycan chains in the antigenicity of Rapana thomasiana hemocyanin. Biochem Biophys Res Commun, Vol.361, No.3: pp. 705-711, 0006-291X

Somasundar, P., Riggs, D.R., Jackson, B.J. \& McFadden, D.W. (2005). Inhibition of melanoma growth by hemocyanin occurs via early apoptotic pathways. Am J Surg, Vol.190, No.5: pp. 713-716, 0002-9610 
Swerdlow, R.D., Ratliff, T.L., La Regina, M., Ritchey, J.K. \& Ebert, R.F. (1994). Immunotherapy with keyhole limpet hemocyanin: efficacy and safety in the MB-49 intravesical murine bladder tumor model. J Urol, Vol.151, No.6: pp. 1718-1722, 0022-5347

Swerdlow, R.D., Ebert, R.F., Lee, P., Bonaventura, C. \& Miller, K.I. (1996). Keyhole limpet hemocyanin: structural and functional characterization of two different subunits and multimers. Comp Biochem Physiol B Biochem Mol Biol, Vol.113, No.3: pp. 537-548, 1096-4959

Szabo, S.J., Sullivan, B.M., Peng, S.L. \& Glimcher, L.H. (2003). Molecular mechanisms regulating Th1 immune responses. Annu Rev Immunol, Vol.21: pp. 713-758, 07320582

Teitz-Tennenbaum, S., Li, Q., Davis, M.A. \& Chang, A.E. (2008). Dendritic cells pulsed with keyhole limpet hemocyanin and cryopreserved maintain anti-tumor activity in a murine melanoma model. Clin Immunol, Vol.129, No.3: pp. 482-491, 1521-7035

Teppema, J.S., de Boer, E.C., Steeremberg, P.A. \& van der Meijden, A.P. (1992). Morphological aspects of the interaction of Bacillus Calmette-Guérin with urothelial bladder cells in vivo and in vitro: relevance for antitumor activity. Urol. Res., Vol.20: pp. 219-228

Timmerman, J.M. \& Levy, R. (2000). Linkage of foreign carrier protein to a self-tumor antigen enhances the immunogenicity of a pulsed dendritic cell vaccine. J Immunol, Vol.164, No.9: pp. 4797-4803, 0022-1767

Torres, M., Manosalva, H., Carrasco, I., De Ioannes, A.E. \& Becker, M.I. (1999). Procedure for radiolabeling gizzerosine and basis for a radioimmunoassay. J Agric Food Chem, Vol.47, No.10: pp. 4231-4236, 0021-8561

van Holde, K.E. \& Miller, K.I. (1995). Hemocyanins. Adv Protein Chem, Vol.47: pp. 1-81, 00653233

van Holde, K.E., Miller, K.I. \& Decker, H. (2001). Hemocyanins and invertebrate evolution. J Biol Chem, Vol.276, No.19: pp. 15563-15566, 0021-9258

Vandenbark, A.A., Yoshihara, P., Carveth, L. \& Burger, D.R. (1981). All KLH preparations are not created equal. Cell Immunol, Vol.60, No.1: pp. 240-243, 0008-8749

Verdijk, P., Aarntzen, E.H., Lesterhuis, W.J., Boullart, A.C., Kok, E., van Rossum, M.M., Strijk, S., Eijckeler, F., Bonenkamp, J.J., Jacobs, J.F., Blokx, W., Vankrieken, J.H., Joosten, I., Boerman, O.C., Oyen, W.J., Adema, G., Punt, C.J., Figdor, C.G. \& de Vries, I.J. (2009). Limited amounts of dendritic cells migrate into the T-cell area of lymph nodes but have high immune activating potential in melanoma patients. Clin Cancer Res, Vol.15, No.7: pp. 2531-2540, 1078-0432

Walsh, W.G., Tomashefsky, P., Olsson, C.A. \& deVere White, R. (1983). Keyhole-limpet haemocyanin (KLH) immunotherapy of murine transitional cell carcinoma. Urol Res, Vol.11, No.6: pp. 263-265, 0300-5623

Weigle, W.O. (1964). Immunochemical Properties of Hemocyanin. Immunochemistry, Vol.1: pp. 295-302, 0019-2791

Wishahi, M.M., Ismail, I.M., Ruebben, H. \& Otto, T. (1995). Keyhole-limpet hemocyanin immunotherapy in the bilharzial bladder: a new treatment modality? Phase II trial: superficial bladder cancer. J Urol, Vol.153, No.3 Pt 2: pp. 926-928, 0022-5347

Wuhrer, M., Robijn, M.L., Koeleman, C.A., Balog, C.I., Geyer, R., Deelder, A.M. \& Hokke, C.H. (2004). A novel Gal(beta1-4)Gal(beta1-4)Fuc(alpha1-6)-core modification 
attached to the proximal $\mathrm{N}$-acetylglucosamine of keyhole limpet haemocyanin (KLH) N-glycans. Biochem J, Vol.378, No.Pt 2: pp. 625-632, 1470-8728

Zhu, J., Wan, Q., Lee, D., Yang, G., Spassova, M.K., Ouerfelli, O., Ragupathi, G., Damani, P., Livingston, P.O. \& Danishefsky, S.J. (2009). From synthesis to biologics: preclinical data on a chemistry derived anticancer vaccine. J Am Chem Soc, Vol.131, No.26: pp. 9298-9303, 1520-5126 


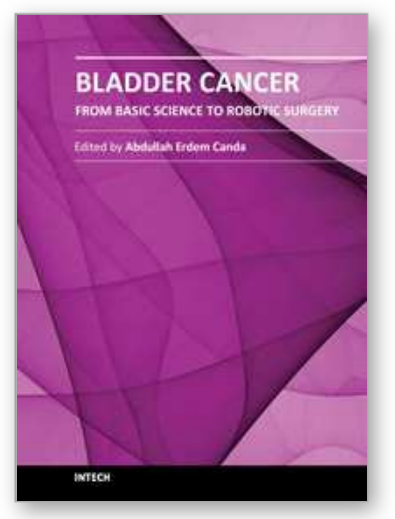

\author{
Bladder Cancer - From Basic Science to Robotic Surgery \\ Edited by Dr. Abdullah Canda
}

ISBN 978-953-307-839-7

Hard cover, 460 pages

Publisher InTech

Published online 01, February, 2012

Published in print edition February, 2012

This book is an invaluable source of knowledge on bladder cancer biology, epidemiology, biomarkers, prognostic factors, and clinical presentation and diagnosis. It is also rich with plenty of up-to-date information, in a well-organized and easy to use format, focusing on the treatment of bladder cancer including surgery, chemotherapy, radiation therapy, immunotherapy, and vaccine therapy. These chapters, written by the experts in their fields, include many interesting, demonstrative and colorful pictures, figures, illustrations and tables. Due to its practicality, this book is recommended reading to anyone interested in bladder cancer.

\title{
How to reference
}

In order to correctly reference this scholarly work, feel free to copy and paste the following:

Sergio Arancibia, Fabián Salazar and María Inés Becker (2012). Hemocyanins in the Immunotherapy of Superficial Bladder Cancer, Bladder Cancer - From Basic Science to Robotic Surgery, Dr. Abdullah Canda (Ed.), ISBN: 978-953-307-839-7, InTech, Available from: http://www.intechopen.com/books/bladder-cancerfrom-basic-science-to-robotic-surgery/hemocyanins-in-the-immunotherapy-of-superficial-bladder-cancer

\section{INTECH}

open science | open minds

\section{InTech Europe}

University Campus STeP Ri

Slavka Krautzeka 83/A

51000 Rijeka, Croatia

Phone: +385 (51) 770447

Fax: +385 (51) 686166

www.intechopen.com

\section{InTech China}

Unit 405, Office Block, Hotel Equatorial Shanghai

No.65, Yan An Road (West), Shanghai, 200040, China

中国上海市延安西路 65 号上海国际贵都大饭店办公楼 405 单元

Phone: +86-21-62489820

Fax: +86-21-62489821 
(C) 2012 The Author(s). Licensee IntechOpen. This is an open access article distributed under the terms of the Creative Commons Attribution 3.0 License, which permits unrestricted use, distribution, and reproduction in any medium, provided the original work is properly cited. 